\title{
$\widehat{A}$ Madridge \\ madridge Journal of Case Reports and Studies \\ interconnecting Scienti
}

Case Report

Open Access

\section{Colon Cancer Recur with Dysphagia}

\author{
Mayada Issa ${ }^{\star}$, and Tyler Buchanan \\ Professor, West Virginia University, WVU Medicineı Medical Center Drive Morgantown, WV, USA
}

\section{Article Info}

\author{
*Corresponding author: \\ Mayada Issa \\ Professor \\ West Virginia University \\ Morgantown, WV \\ USA \\ Tel: 3042931964 \\ E-mail: mayada.issa@gmail.com
}

\section{Received: December 29, 2018 \\ Accepted: February 27, 2019 \\ Published: March 5, 2019}

Citation: Issa M, Buchanan T. Colon Cancer Recur with Dysphagia. Madridge J Case Rep Stud. 2019; 3(1): 112-113.

doi: $10.18689 /$ mjcrs-1000127

Copyright: ๑ 2019 The Author(s). This work is licensed under a Creative Commons Attribution 4.0 International License, which permits unrestricted use, distribution, and reproduction in any medium, provided the original work is properly cited.

Published by Madridge Publishers

\section{Introduction}

Here we present the rare case of a patient with inadequately treated colon cancer, due to refusal of chemotherapy, who presented with difficult swallowing and was found to have colonic metastasis to the distal esophagus. Of the approximately 135,000 cases of large bowel cancer diagnosed each year in the United States, 95,520 cases are colon of those diagnosed with colon cancer, approximately $20 \%$ will have distant metastases at the time of presentation [1]. colon cancer metastasis to the esophagus is rare and presentation is limited to few isolated case reports. In this report, we present our experience with a patient with a history of colon cancer who developed difficulty swallowing due to esophageal metastases.

Keywords: Cancer; Oncology; Hemicolectomy; Chemotherapy; Capecitabine.

\section{Case Presentation}

A 70 years old male with a past medical history significant for hypertension, hyperlipidemia, and colon cancer presented to our emergency department with a onemonth history of difficulty swallowing. The patient stated that his symptoms began as a sore throat one month prior to presentation and progressed to difficulty swallowing solid foods then to difficulty swallowing liquids. Of note, the patient denied odynophagia and dyspnea. Social history was significant for smoking cigarettes from age thirteen until he was sixty years old at which point he started using snuff, and he used to drink alcohol daily in his early twenties for six years quitting thereafter. Family history was significant for a brother with esophageal cancer and a mother with metastatic cancer of unknown origin; however, family history was negative for colon cancer. Two years prior to presentation at our emergency department, he was diagnosed with stage III colon cancer, which had presented as a partial bowel obstruction. The patient underwent hemicolectomy, and due to two out of nineteen nodes being positive, chemotherapy was recommended; however, the patient declined chemotherapy. Due to insurance issues, the patient failed to follow up with oncology following hemicolectomy. His last colonoscopy was two months prior to current presentation demonstrated no significant findings.

Initial evaluation of the patient included CBC, electrolytes, and liver enzymes, all of which were found to be within normal limits. CEA was $1.6 \mathrm{ng} / \mathrm{mL}$. ACT scan of his chest showed an infiltrative mass-like density in the proximal esophagus with stranding in the left superior mediastinum possibly related to the presence of a metastatic lymph node, along with numerous small bilateral pulmonary nodules concerning for metastatic disease (Figureure 1). Given the concerning nature of his CT results, an EGD was performed and reported mild stricture in the proximal esophagus at $22 \mathrm{~cm}$ with some nodularity and no ulceration. Biopsy of the stricture showed intact squamous mucosa with underlying atypical glandular proliferation and moderately differentiated adenocarcinoma involving the muscularispropria indicating metastatic disease. Malignant cells were positive for CK 20 and CDX2 and negative for CK7 and TTF 1 
phenotypically compatible with colorectal primary cancer. There was no Barrett's esophagus at the site of the biopsy supporting the diagnosis of a metastatic lesion rather than a primary esophageal cancer.

Management of the patient's metastatic colon cancer included radiation and maintenance with chemotherapy. The patient received radiation to the colon cancer metastasis of the esophagus and para-aortic lymph nodes. Adjunctive chemotherapy included maintenance oral Capecitabine. PET CT scan at that time noted decreased size of the paraesophageal mass, demonstration of the multiple pulmonary nodules with minimal metabolic activity. Five months later, follow up PET scan showed new skeletal metastasis in the left iliac bone consistent with disease progression. The patient had also lost about ten pounds of weight, yet he wanted to continue Capecitabine and not to change treatment.

\section{Discussion}

Metastasis to the esophagus is rare and has most frequently been shown to arise from breast or lung cancer [2]. Literature search for case reports of large bowel carcinoma metastasis to the esophagus was able to recapitulate the rarity of our own report, yielding only 4 reports to date [3-6].

In our case, the presence of intact mucosa and the involvement of the sub mucosa and muscular is layers with cancer cells indicated the diagnosis of metastatic disease. However due to the limitation of the metastatic lesions to the submucosal space, it is not uncommon for an endoscopic biopsy to miss the diagnosis, especially with a macroscopically normal mucosa $[2,7]$. Hence, patients presenting with dysphagia in the setting of a known history of malignancy should be examined with caution, and metastasis to the esophagus should remain on the differential.

\section{Author Disclosure Statement}

The authors deny any conflict of interests or funding sources associated with this research study. No competing financial interests exist.

\section{References}

1. Siegel RL, Miller KD, Jemal A. Cancer Statistics, 2016. CA Cancer J Clini. 2016; 66(1): 7-30. doi: 10.3322/caac.21332

2. Simchuk EJ, Low DE. Direct esophageal metastasis from a distant primary tumor is a submucosal process: a review of six cases. Dis Esophagus. 2001; 14(3): 247-250.

3. Fischer MS. Metastasis to the esophagus. Gastrointestinal Radiol. 1976; 1: 249-251.

4. Lohsiriwat $\mathrm{V}$, Boonnuch $\mathrm{W}$, Suttinont $\mathrm{P}$. Esophageal metastasis from rectal carcinoma. J Clini Gastroenterol. 2005; 39: 744

5. Vashi PG, Gupta D, Tan B. Colon Carcinoma with Unusual Metastasis to the Esophagus Manifesting as Multiple Nodules and Dysphagia: Management with Systemic Chemotherapy. Case Rep Gastroenterol. 2012; 6(2): 484-488. doi: 10.1159/000341587

6. Thomasset SC, Garcea G, Berry DP. Oesophageal Metastasis from Colorectal Cancer. Case Reports in Gastroenterology. 2008; 2(1): 40-44. doi: $10.1159 / 000113217$

7. Anderson MF, Harell G.S. Secondary esophageal tumors. AJR AM J Roentgenol. 1980; 13(5): 1243-1246. doi: 10.2214/ajr.135.6.1243 